MANDALA:

Jurnal Ilmu Hubungan Internasional

Received: 25-08-2020

Accepted: 29-08-2020

Published: 04-11-2020

\title{
Examining The International Relations Theory Of The Asia Pacific Syaiful Anam
}

Lecturer, Department of International Relations. University of Mataram, NTB

s.anam@unram.ac.id

\begin{abstract}
The question whether the IR theories used to analyse and study the Asian region particularly Asia Pacific is relevant or not remains heatedly debated within the field itself. Prominent scholars such as David C. Kang, Barry Buzan, and Peter Katszeinstein, and Amitav Acharya have argued through their works that the study of Asian region is often analysed by IR theories that is dominated by the Western knowledge and experiences. This essay hence would like to examine which theories are the most relevant and useful to depict and explain the dynamic of international relations in Asia, particularly the Asia Pacific. It argues that IR theories that cover the dynamics of international, historical and social relations of the Asian countries would likely the most useful and relevant to analysing the IR of the Asia-Pacific.
\end{abstract}

Keywords: Asia Pacific, International Relations Theories, Realism, Liberalism, Constructivism

\begin{abstract}
Abstrak
Pertanyaan mengenai apakah teori HI yang digunakan untuk menganalisis dan mempelajari wilayah Asia, khususnya Asia Pasifik, relevan atau tidak, masih menjadi perdebatan hangat dalam bidang itu sendiri. Para ahli terkemuka seperti David C. Kang, Barry Buzan, dan Peter Katszeinstein, dan juga Amitav Acharya telah berpendapat melalui karya-karya mereka bahwa studi wilayah Asia sering dianalisis oleh teori IR yang didominasi oleh pengetahuan dan pengalaman Barat. Tulisan ini karenanya berusaha mengeksplorasi teori mana yang paling relevan dan berguna untuk menggambarkan dan menjelaskan dinamika hubungan internasional di Asia, khususnya Asia Pasifik. Tulisan ini berpendapat bahwa teori-teori HI yang mencakup dinamika hubungan internasional, historis dan sosial dari negara-negara Asia kemungkinan akan paling berguna dan relevan untuk menganalisis hubungan internasional di Asia-Pasifik.
\end{abstract}

Kata Kunci: Asia Pasifik, Teori Hubungan Internasional, Realisme, Liberalisme, Konstruktivisme 


\section{Introduction}

In his fascinating book, 'East Asia before the West: Five Centuries Trade and Tribute', David C. Kang (2010) has demonstrated that the history of the East Asia's international relations had completely different social and cultural pattern from those in Europe.

Through his historical analysis on the early modern ages of East Asia, Kang investigated how China shaped the regional international order with its tribute system. This tribute system had maintained the regional cooperation between China and other neighbor countries such as Japan, Korea, and Vietnam for almost six centuries. The system was also evident to prevent high intensity of war and thus created a peaceful region at that moment. In this case, as Kang outlines in his chapter three, China did not utilise military approach nor China exercised its coercive politics upon other states. Instead, to maintain its external relations with other political actors in the region China remained to respect other states' political sovereignty as well as their independence on several underlying issues such as economic and legal system, and government institutions (Kang, 2010:81). Hence, it clearly shows that East Asia's foreign affairs dynamic at that time had indeed a major different pattern from the Westphalia state system of Europe.

Given the difference pattern and social-cultural system employed between Europe and East Asia, does it mean that the analysis of East Asia's history suggest that Western international relations theories or approaches should be challenged? The problem of international relations theories that is too "Western" used to analyse other distinctive region such as Asia is prevalent within the discipline itself. Elsewhere Kang (2003) has also outlined, quoted Kenneth Waltz's statement, "The theory of international politics is written in terms of the great powers of an era. It would be ridiculous to construct a theory of international politics based on Malaysia and Costa Rica...A general theory of international politics is necessarily based on the great powers" (in Kang, 2003:57). It is common then, as Kang (2003) had argued, to utilise international relations theory based on European experiences to capture East Asia, for instance. The theory itself is not false, as Kang added, but it indeed cannot completely capture the uniqueness and the distinctiveness of the region that has basically different experiences with the European has. As well as Kang, Amitav Acharya (2007) has pointed out that even among IR scholars in Asia, debate and 
disagreement evolve upon the relevance of IR theory to studying Asia given that its historical tradition, practical and intellectual discourses are based on Western experiences (Acharya, 2007:1). Considering these accounts that Kang and Acharya have outlined, so which theoretical approach (s) in international relations is/are the most useful and relevant to analyse the international relations of the Asia Pacific in particular?

In regard to the problems outlined above, this essay argues that Western IR theory used to analyse the East Asia's history should be challenged in term of its monolithic-Eurocentric approach. It is no longer valid nor relevant to explain the dynamic of the IR of the Asia Pacific as the cultural, historical and social relation in the region are different and distinctive compared with the Western experiences. It is not simply to ignore all IR theories. Instead, IR theories that cover the dynamics of international, historical and social relations of the Asian countries would likely the most useful and relevant to analysing the IR of the Asia-Pacific. To substantiate this argument, it will be divided into three parts. First, it will be discussing on how the Western IR theories shapes theoretical and intellectual discourses of Asian studies. It will also be continued by discussing the 'complete picture' of international relations of the East Asia/Asia Pacific, in other words, what does it tell us about IR in the region?.This part accordingly will specifically lead to examine whether the existing Western IR theories are relevant for analysing IR in Asia. The second part then will be examining theoretical approaches in IR theories that will be the most relevant and useful for the study of IR in Asia Pacific. It will mainly be focusing on examining the relevance of three theoretical approaches in IR: Realism, liberalism, and constructivism, to analyse the Asia Pacific. The last part will then be the conclusion of this essay.

\section{The Debate Upon IR in East Asia/Asia Pacific}

The question whether the IR theories used to analyse and study the Asian region particularly Asia Pacific is relevant or not remains heatedly debated within the field itself. Scholars such as David C. Kang (2003;2005), Barry Buzan, and Peter Katszeinstein (1997;2007), and Amitav Acharya $(2003 ; 2005 ; 2007)$ argue through their works that the study of Asian region is often analysed by IR theories that is dominated by the Western knowledge and experiences. These scholars believe that the theories are inadequate and not relevant to study the Asian region since it 
has different historical traditions, intellectual discourse, and socio-cultural experiences than those in Europe. Katzenstein, for instance, pointed out that, "Theories based on Western, and especially West European experience, have been of little use in making sense of Asian regionalism" (Katzenstein, 1997:5) Likewise, Kang (2003) acknowledged that the IR theories preoccupied by Western experiences is likely insufficient to explain complex phenomenon in the region such as Asia that has a distinct historical trajectory compared with European states. Kang stated that "Most international relations theory is inductively derived from the European experience of the past four centuries, during which Europe was the locus and generator of war, innovation, and wealth". For Kang, even if the scholars of international relations paid their attention to the study of other regions, it might put the regions as the peripheral subject such as third world security or the behavior of small states. Accordingly, the Western knowledge is not relevant to study or even generalise other regions including Asia Pacific (Kang, 2003: 58).

Moreover, Kang's analysis on his book "East Asia before the West: Five Centuries of Trade and Tribute" (2010) basically attempt to challenge the Western approaches in the study of IR by highlighting the distinctiveness of Asian historical traditions. Kang's main concern is to show that the frequent conflict and bloody war happened in early modern Europe was not similar than those experienced in East Asia. This region at that moment had indeed experienced stability and established peaceful relations between surrounding states. Kang argued that this condition was enabled by the system being developed by China called the tribute system. Within this system, China is the center and it served as a benign hegemon in the region, not exploiting other neighbor states and creating a framework for acceptable social norms and credible commitment so that China's authority can be accepted by other states. Therefore, according to Kang, the tribute system as well as the trade relations put China in the center had created a more peaceful region in East Asia rather than the European's nation-states system surviving for the balance of power and territory.

In contrast, scholars such as John Ikenberry and Michael Mastanduno (2003) claim that the Western theoretical approaches as a tool analysis of the international relations in Asia are still relevant. Although it is viewed that interstates relations in Asian region might have some different features with those in 
Europe, these differences had been obscured by the integration of the states in the region into a modern international system developed by Western approaches in which the pattern of international relations in Asia itself has been formed by similar features of the Westphalian system. Therefore, the main theoretical concepts of international relations such as the balance of power, international regimes, hegemony, and distribution of power become relevant in studying and analysing any regions including Asia Pacific. The proponent of this idea, Hugh White (2008), for instance, proposed a Western historical experience in analysing contemporary international relations of the Asia Pacific. He claimed that the concept of European concert can be applied in the Asia Pacific region as a mechanism to prevent the potential of war in the region that might likely caused by the China and the US' rivalry. White is optimistic that this concept is a promising model for maintaining the stability, peace, and security of the Asia Pacific region. For the supporter of this idea, it is claimed that the concert could significantly resolve any crisis situation in the Asia Pacific region through consultation conducted by regional major powers. In this circumstance, the great powers' role would likely to ensure the stability of the region because any changes potentially influence the peace and stability of the region have to gain prior agreement of the major powers. Furthermore, the concert's principles which hold the equality among members will likely build the relationships of the states and major power and hence any conflicts between states and major powers can be moderated (Khoo \& Smith, 2001).

While White, Ikenberry, and Mastanduno claimed that Western approaches in IR theories are still relevant in studying IR in Asia, it could be argued that there are some underlying factors that often neglected within the approaches and it hence makes the approaches becomes failed to deeply analyse the IR in Asia Pacific. The first is the nature of Asian states. Although it is superficially seen that Asian countries are adopting Westphalian system, they do not actually experience the same process of development like the Western countries. In fact, pressures and issues that brought development into the nation state system in the European are not similar with those in the Asian countries. Asia has actually different cultural, political and historical traditions and thus it would not be surprising if the pattern of international relations of the Asia do not necessarily resemble like in the West. The second concern is the historical path of the 
Asian nations that bring them within the larger international system. The postcolonial legacy in the Asian region remains explicit in the behaviors and interactions among nations in Asia. Philippines has close relations with the US and it is quite influencing its political institution even its social life such as the passion in basketball. Meanwhile, China, Japan, and Korea are still having complex relationship due to their past historical experiences involved war and conflict. For the Southeast Asia countries, it was the place where the great civilizations such as Muslim, Chinese, Indian intersect. Conflict and problem in these countries might be related to the former colonial systems that are still utilised by each country. Hence, through this historical path and the nature of state it can be seen that the Asian nation-states inter-relations and dynamics might include different element and experiences than those in the West. The Western approaches or concepts to analyse the IR in Asia should not be taken for granted if it remains fully oriented on the Western knowledge and experiences. Rather, it should include the particular element found in the culture, social, and history of Asian nations (Kang, 2003).

Nevertheless, although it seems that Western theoretical approaches inadequately capture the specific elements that influence the dynamics and patterns of IR in Asia, it sees that Western theories such as realism, liberalism, and constructivism have much contribution to the development of the study of IR in general. Apart from their ethnocentrism, these theories should not be neglected. Instead, it should be universalised by including elements related to the context, culture, and history of the IR and development of the Asia. The next part of this essay therefore will be examining these theories. It will be exploring the theoretical debate within each theory and identifying what approaches might be relevant and useful for the study of Asia Pacific.

\section{Examining the International Relations theories of the Asia Pacific}

\section{Realism}

Realist considers state as the main actor in international relations and anarchy as an order of the international system in which states interact with each other. Since the international system is an anarchy, which there is no authority above states, states hence are mainly guided by their national interests and power. This circumstance then makes state to endlessly compete for power and influence each other that eventually lead to a conflict. The 
appearance of institutions and organizations, for realist, is maintained simply for a way of manipulating the balance of power. This classical realist perspective later was evolved into what is commonly known as neo-realism developed by Kenneth Waltz (1964). The main idea of neo-realism is that the stress upon the structural dimension of the international system (i.es the distribution of power), particularly its role in establishing order and shaping conflict. Debate within this school of thought is currently showed between a so-called "offensive realist" and "defensive realist". The former stresses on the role of states as a power maximizer in which their ultimate goal is only for gaining their national interest through power hegemony. Meanwhile, the latter contends that states would tend to maintain the status quo if there are no any significant threats challenge their security, which means that states attempt to maintain the balance of power (in Acharya, 1997).

The centrality of the realist upon the idea of balance of power becomes the rationale to understand the dynamic of international relations, particularly in the region such as Asia Pacific. In understanding the Asia pacific, realist sees that the balance of power is the main element of shaping the order of Asia
Pacific in which the US is the main actor for balancing the regional power. Lee Kuan Yew, a Singaporean's statesman, supports this idea by arguing that the presence of the US in the region has significantly contributed not only in securing the areas from power expansion of China and Soviet but also in building a robust economy and stability of the Asian states (Acharya \& Tan, 2005).

In analysing the end of the Cold War, realist, particularly neo-realist, argued that the end of bipolarity system preoccupied Asia during the Cold War would lead the region into an unstable condition and disorder. Bipolarity, rather than multipolarity, is regarded by neorealist to be more stable and capable in maintaining the order and preventing region from the blast of overt conflict (Waltz, 1964). Moreover, the end of the Cold War, for neo-realist, means that there was a vacuum of power in the region. It can be seen, for instance, from the decision of Soviet to withdraw its naval facilities in Cam Ranh Bay, Vietnam and the US' decision to dismantle its air bases and naval in the Philippines (Acharya, 2007).

The discourse of the vacuum of power in the Asian region then led the school into an analysis upon who will be filling it. Realist initially foresaw that the multipolar system in Asia would 
demonstrate the rising of China as a new regional power and the military contestation between Japan and India. However, the rising of China in term of its economic growth and military spending put China as the main topic. Realist argued that the confrontation between the US, as the status quo power, and China, as a newly rising power, is inevitable. For the offensive realist's point of view, an inevitable confrontation does make sense because great powers are likely to have a tendency for expanding their power and thus clash between two great powers are inevitable. Mersheimer (1990), a proponent of this idea, deemed the rising of China is just like the US' experience in the $19^{\text {th }}$ century in which the US at that moment was attempting to spread its influences and establish its hegemony upon adjacent neighbors. Expansionism, hence, for Mersheimer (2001), is not a built-in element within a rising power but it is indeed because of the anarchical system that leads states for a survival. The concern towards survival accordingly makes states, both powerful states and weak states, to feel a survival anxieties and it drives most of powerful states to conduct expansionism.

The contributions of realism can be considered as significant both in the study of Asian region and in the policy implementation, particularly on the notion of the balance of power in the region. Moreover, both in academic and policy writings during and after the Cold War realism were the dominant perspective in analysing the international relations of the Asia (Vasquez, 2002). Despite its contribution, realism has also been challenged. For instance, the realists' argument on the US's central role in making stability in the Asia has undermined the contribution of other factors such as norms and institutions evolving in the Asian region, rapid economic growth and the dynamic of domestic politics. Furthermore, realism's notion claims the Cold War bipolarity can maintain stability in the region casts a doubt. It might be argued by the realist that the bipolarity could prevent two superpowers from a direct war, but the fact that it failed to avoid many conflicts occurred between the allies of the superpowers or between one of the superpower against the allies of its opponent (Alagappa, 2003). This experience hence can be used to analyse the balance of power between the US and China in this post-Cold War era in which the contestation between those great powers might unlikely prevent the region from the outbreak of regional conflict that 
might cause instability and destruction in the region.

\section{Liberalism}

Liberalism, unlike realism that is concerned on issues such as security and order, is more focused on the issues of international political economy. In seeing international relations in Asia Pacific, liberal perspective regards that the underlying foundation of the post-war order in Asia is neither based on different region or culture nor the issues of security in the region. Instead, it was built by the international economy order under the US hegemony. The US plays crucial role in the region in making several international institutions and regimes such as the World Bank, the IMF, and the GATT, which have significant role in disseminating the economic liberalism' norms. The expansion of this norm in the Asia Pacific enables the US to play its role as a 'friendly' hegemon in ensuring the rapid growth of Asian's economies which furthermore create stability upon the domestic politics of each state in the region (Acharya, 2004).

In analysing the international relations of the Asia Pacific, the liberal conception put its concern on how peace in the region could be established by the role of states' interdependence. This argument underpins the liberalist's view that the rising of China would likely to be peaceful. However, this argument is much criticised particularly from realist who argued by taking the experience of European economic interdependence wherein it could not avoid the First World War. Responding this challenge, liberalist emphasises on the different context between the former and the later. The former was taking place in $19^{\text {th }}$ century context in which economic interdependence was driven by trade and exchange, while the latter is based on transnational production which might has great impact to domestic politics and national security if it is failed to be maintained (Acharya \& Buzan, 2007).

Another core idea of the liberalism advocates the theory of democratic peace has given insignificant contribution on the study of IR in Asia. It is not surprising because the Asian countries which historically have only few democracies cannot examine this theory. In fact, the democracies in the Asian countries emerge in a form of "illiberal variety", challenging the concept of liberal peace advocated by this theory. Peace in Asia hence could be seen as an illiberal peace in which peace is not initiated by the democratic government, it is indeed established by the authoritarian and semi-authoritarian states 
that prevent conflict and war through economic cooperation, performance legitimacy and the role of organization or institutions which respect the sovereignty of each state (Acharya \& Stubbs, 2007). Therefore, the liberal-democratic peace argument has little contribution in the study of Asia. In fact, it invites much critics since the democratic transitions took place had created more danger in the region, especially in the Southeast Asian countries.

Narrowing more into the analysis of classical liberalism which holds the idea of collective security and regional integration, it has indeed no significant implication towards the study of IR in Asia Pacific since the region does not have any form of collective security or supranational institutions. The focus upon the dynamic of international institution has brought classical liberalism to believe that regional peace and integration might be enabled because of the role of institution that could enhance the cooperation among states (Wan, 2007). However, this approach is more focused on international regime rather than collective security. Moreover, the analysis on regional institutions in Asia such as APEC and ASEAN has attracted classical liberalism, yet the ideas of norms and cultural identities developed by constructivism have been much utilised to analyse the regional institutions dynamic in Asia rather than the classical liberalism's notions of collective security and regional integration (Acharya, 2005). Therefore, it can be seen that, as discussed above, the liberalism's concern on the interdependence, democratic peace, collective security and regional integration in general has few impacts on the study of IR in the Asia.

\section{Constructivism}

In analysing the IR of the Asia, constructivist claims that collective identities play important role in shaping the dynamic of the region. Constructivists such as Peter Katzenstein (1997) and Chris Hemmer (2002), for instance, tried to analyse the inexistence of NATO in Asia by investigating the collective identity advocated by the policy makers in the US towards its relations with Europe and Asia. In this case, the US policy makers during the post-war period regarded Europe as its important allies rather than Asia. Asia was seen as either unequal or inferior by the US. Consequently, the US put its greater priority to engage close relationship with Europe than Asia and hence the creation of NATO in Europe was more desirable (Acharya, 2005).

Furthermore, constructivist has also analysed the factor cause the emergence of 
Asian regionalism that is different than other regions. This regionalism, for constructivist, reflects the norms and belief of Asian cultures and shows the collective identities of Asian states striving to establish their national and regional autonomy (Acharya, 1997). One example of the regionalism in Asia is the establishment and the evolution of ASEAN. Constructivists contend that the establishment of ASEAN in 1967 cannot be explained through the realist or liberal perspective. Constructivists argue that ASEAN was not formed because of the perception of its members regarding the absence of their common external enemy, as realists argue, and of a strong interdependence among the member of ASEAN, as liberalist contend. Rather, the emergence of ASEAN was underpinned by the share norms, beliefs, and ideas among its members. For instance, the norms of non intervention, equality among member states and non cooperation with any great power military alliances had shaped the uniqueness of ASEAN regionalism which commonly known as the ASEAN Way (Acharya \& Stubbs, 2007).

The discussion of regional institutions has thus become the core understanding of constructivist in studying and analysing the international relations in Asia's post war period. Through debate and discussion about Asia institutions constructivist tried to apply and test its concepts on how the role of norms and ideas have shaped the dynamic of IR in Asia, particularly the case of ASEAN. Through constructivist analysis, it can be found the difference of regionalism occurred in Europe and Asia. The nature of the former is more bureaucratic, legalistic and formal, while the latter is informal, adopting a processcentric conception and consensual. Therefore, constructivists argue that it will be likely improper to assess the effectiveness of Asian institutions performance by simply using the criteria taken from the experiences and knowledge of the European regionalism. (Katzenstein, 2007).

Through the analysis of constructivism it has illuminated the understanding of the pattern and dynamic of IR in Asia. Its focus on the role of norms, ideas, cultures and identities has enriched the field of IR that is dominated by the material and non ideational perspectives. Constructivists have also challenged the taken-for-granted analysis of the realists and neo-realists that see the balance of power system as a core order underpinned the regionalism in Asia by proposing the role of ideational factors in shaping the transformation and change in the Asian region. At last, constructivists 
have introduced the diversity within the conception and theory of the international relations field and have bridged the traditional approaches of area studies used for analysing the Asian region to a wider scope of international relations theories.

\section{Conclusion}

The international relations of the Asia, or particularly Asia Pacific, is obviously different with those in Europe. What European states have experienced might likely not happened in Asia. The history of East Asia's international relations as shown by Kang has demonstrated that China as a regional superpower did not exploit its neighbor countries. Instead, China played its role as a benign hegemon and had created acceptable social norms that frame the cooperation and international affairs among Asian states at that time. Moreover, the European's Westphalia system has never been precisely adopted in Asia. China had contrary applied a different international order than in Europe called the tribute system. The system had maintained the regional peace and security and as well as intensified the cooperation and trade among states. In addition, the historical path and the nature of Asian states have shown different pattern than in Europe. The diversity of ethnics, culture, social, religion, and civilization as well as the influence of the colonial legacy have brought the nations to face different pattern of development compared with the European's experiences. In seeing contemporary Asia Pacific, the Western knowledge and experiences used to approach and analyse the IR of Asia are likely insufficient and irrelevant and hence IR theories that are too western should be challenged. However, the question then, what theories or approaches might be relevant for analysing IR in Asia Pacific? This essay considers three mainstream approaches in the field such as realism, liberalism, and constructivism to be examined in order to find the most relevant and useful theory for the IR of Asia Pacific. Although these theories are dominated by the Western knowledge and experiences, they have much contribution to the development of the IR field study. In regard to the Asian IR, realism is the mainstream approach to analyse the region during and after the Cold War era. Particularly during the Cold War era, the bipolarity balance of power had put the theory as the main approach both in policy and academic writings. At the end of the Cold War, however, the popularity of realism was challenged by liberalism and constructivism. The emergence of new regional institutions such as ARF, EAS, and of the events such as the signing of 
South China Sea Declaration on the Code of Conduct, have given optimism to the liberalist and constructivist. Moreover, it seems that constructivism will have greater attention to the study of Asia IR as its concern stresses on the issues such as norms, identity, and culture. However, while these theories have much contribution to the study of IR, including Asian IR, they have been much criticized as discussed in the essay. Hence, it sees that theories that relevant for studying and analysing IR of the Asia should not be oriented from any single theory discussed above. Rather, those theories (realism, liberalism, and constructivism) should be synthesized and be universalized by including particular elements of the Asian's society, culture, and identity. Therefore, a new approach or theory might be needed for the IR of Asia, an approach or theory that is synthesized from the great traditions in IR field study and can include the diversity of the Asian states.

\section{References}

Acharya, A 1997, 'Beyond anarchy: Third world instability and international order after the Cold War", in Stephanie Neumann, ed., 'International Relations Theory and the Third World', New York: St Martin's Press.
Acharya, A 2003, 'Will Asia's past be its future?", International Security, vol. 28, no.3 (Winter 2003-04).

Acharya, A 2004, 'How ideas spread: Whose norms matter? Norm localization and institutional change in Asian regionalism", International Organization, vol. 58, no.2, pp. 239-275.

Acharya, A 2005, 'Why is there no NATO in Asia? The normative origins of Asian multilateralism," Working Paper No. 05-05, Weatherhead Center for International Affairs, Harvard University

Acharya, A and Tan, SS 2005, 'Betwixt balance and community: America, ASEAN, and the security of Southeast Asia, International Relations of the Asia-Pacific, Vol. 5 , No. 2

Acharya, A 2005, 'Do norms and identity matter? Community and power in Southeast Asia's regional order," Pacific Review, vol.18, no.1, pp.95118

Acharya , A and Buzan, B 2007, 'Why is there no non-Western IR theory: An introduction,' in Amitav Acharya and Barry Buzan, 'Conclusion: On the possibility of a Non-Western IR theory in Asia, International Relations of the Asia- 
Pacific.

Acharya, A and Stubbs, R 2007, 'Theorising Southeast Asian Relations: An introduction," in Acharya and Stubbs, eds., "Theorising Southeast Asian Relations: Emerging Debates, 2007.

Alagappa, M 2003, 'Introduction,' in Alagappa, ed., Asian Security Order: Normative and Instrumental Features, Stanford: Stanford University Press.

Hemmer, C and Katzenstein, PJ 2002,

'Why is there no NATO in Asia:

Collective identity, regionalism, and the origins of multilateralism,'

International Organization, Vol.

56, No.3, pp. 575-607.

Ikenberry, J\& Mastanduno, M 2003,

'International Relations theory and the Asia-Pacific, New York: Columbia University Press, pp. 421-2.

Kang, DC 2003, 'Getting Asia wrong: The need for new analytical frameworks', International Security 27, no. 4, pp. 57-85.

Kang, DC 2010, 'East Asia before the West: Five centuries of trade and tribute', New York: Columbia University Press.

Katzenstein, PJ 1997, 'Introduction: Asian regionalism in comparative perspective,' in Peter J. Katzenstein and Takashi Shiraishi, eds., 'Network Power: Japan and Asia', Ithaca, N.Y.: Cornell University Press, pp. 5.

Katzenstein, PJ 2007, 'Introduction: Asian regionalism in comparative perspective', in Amitav Acharya and Alastair Iain Johnston, eds., Crafting Cooperation: Regional International Institutions in Comparative Perspective, Cambridge: Cambridge University Press.

Khoo, N \& Smith, ML 2001, 'Concert of Asia?', Policy Review: Aug/Sept 2001, pp. 73

Mearsheimer, JJ 1990, 'Back to the future: Instability in Europe after the Cold War", International Security, vol. 15, no.1, pp. 5-55.

Mearsheimer, JJ 2001, 'The Tragedy of Great Power Politics',New York: W.W. Norton \& Company, pp. 41. Vasquez, J 2002, 'Realism and the study of peace and war', in Michael Breecher and Frank P. Harvey, eds., Realism and Institutionalism in International Studies, An Arbor: University of Michigan Press.

Walt, SM 1998, 'International Relations:

One world, many theories', 
MANDALA:

Jurnal Ilmu Hubungan Internasional

Foreign Policy (Spring 1998),

pp.29-46.

Waltz, KN1964, 'The stability of the

bipolar World", Daedalus, Vol. 93

(Summer 1964), p. 907

Wan, M 2007, 'Economic interdependence and economic cooperation," in Alagappa, ed., Asian Security Order; Benjamin E. Goldsmith, "A Liberal Peace in Asia? "Journal of Peace Research, Vol. 44, No. 1, pp. 5-27

White, H 2008, “ Why war in Asia remains thinkable', Survival: Global Politics and Strategy, 50:6, pp.85104. 